\title{
Sistem Kerja Storage Dan Purchasing Department Terhadap Kelangsungan Operasional Di Hotel Jambuluwuk Malioboro Yogyakarta
}

\author{
Indri Kholifatun ${ }^{1}$, Jati Nurcahyo ${ }^{2}$ \\ Akademi Pariwisata BSI Yogyakarta \\ E-mail : Indri_kholifatun@gmail.com ${ }^{1}$, r.jno@bsi.ac.id ${ }^{2}$
}

\begin{abstract}
Abstrack: In fulfilling the operational needs at Hotel Jambuluwuk Malioboro Yogyakarta certainly needs equipment, equipment and materials for both material and ready to use operations. The existence of Purchasing Department authorized to make purchases of all hotel goods will facilitate the operational process. With the purchase of goods, the hotel provides a warehouse as a place to store all hotel items held by Storage Department. Storage Department especially receiver in charge of receiving goods orders from Purchasing, while store keeper who organize and serve the demand of goods from other Departments in Hotel Jambuluwuk Malioboro. Faktor Slow Storage Department in the process of receiving goods from suppliers who come kehotel usually not as easy as seen. Of the many goods that come, there is usually a mistake of the supplier and mistakes, Storage and Purchasing Department working system at Hotel Jambuluwuk Malioboro Yogyakarta has one department other than other hotels, namely the Department of Materials Management in which the Management Materials in it a combination of Storage and Purchasing Section. Workspaces are combined into one between Storage and Purchasing facilitate the work process when encountering an obstacle. In the process of work there are several paths that are the responsibility of Storage and Purchasing. The following workflow ranging from the procurement of goods from the branch, the demand for goods for the user (department request), purchase of goods, until the receipt of goods from Purchasing. This methodology uses descriptive qualitative method of describing events / events experienced by reality. Working system Storage and Purchasing Department ranging from procurement of goods from the branch, the demand for goods for the user, the purchase of goods, until the acceptance of goods from suppliers. All of these processes certainly have some obstacles that delayed the work. Interconnection during operation between Storage and Purchasing Department will minimize the constraints that will occur, so that the professionalism of work will be established for the achievement of satisfaction for guests
\end{abstract}

\section{Keywords: Storage Department, Purchasing Department, Operational}

Abstrak: Dalam memenuhi kebutuhan operasional di Hotel Jambuluwuk Malioboro Yogyakarta tentu membutuhkan peralatan, perlengkapan dan bahan-bahan untuk operasional baik material maupun siap pakai. Adanya Purchasing Department yang berwenang melakukan pembelian segala barangbarang keperluan hotel akan memudahkan proses operasional. Dengan adanya pembelian barang, hotel menyediakan gudang sebagai tempat menyimpan semua barang hotel yang dipegang oleh Storage Department. Storage Department khususnya receiver bertugas menerima barang pesanan dari Purchasing, sedangkan store keeper yang menata dan melayani permintaan barang dari Department lain di Hotel Jambuluwuk Malioboro. Faktor yang Memperlambat Storage Department dalam Proses penerimaan barang dari supplier yang datang kehotel biasanya tidak semudah yang dilihat. Dari sekian banyak barang yang datang, biasanya terdapat kesalahan dari supplier dan kesalahan, Sistem kerja Storage dan Purchasing Department di Hotel Jambuluwuk Malioboro Yogyakarta memiliki satu departemen yang lain dari hotel lainnya, yaitu departemen Material Manajemen yang mana Material Manajemen didalamnya gabungan dari Storage dan Purchasing Section. Ruang kerja yang digabung menjadi satu antara Storage dan Purchasing memudahkan proses kerja apabila menemui suatu hambatan. Dalam proses kerjanya ada beberapa alur yang menjadi tanggung jawab Storage dan Purchasing. Berikut alur kerja mulai dari pengadaan barang dari cabang, permintaan barang untuk user (departemen yang meminta), pembelian barang, sampai penerimaan barangdari Purchasing. Metodelogi ini menggunakan metode deskriptif kualitatif yaitu mendeskripsikan kejadian/peristiwa yang dialami sesuai kenyataannya. Sistem kerja Storage dan Purchasing Department mulai dari pengadaan barang dari cabang, permintaan barang untuk user, 
pembelian barang, sampai penerimaan barang dari supplier. Semua proses tersebut tentu mengalami beberapa kendala yang membuat tertundanya pekerjaan. Kerterkaitan selama operasional antara Storage dan Purchasing Department akan meminimalisir kendala yang akan terjadi, sehingga profesionalisme kerja akan terjalin demi tercapainya kepuasan bagi tamu.

Kata Kunci: Storage Department, Purchasing Department, Operasional

\subsection{Latar Belakang}

Dunia pariwisata untuk saat ini sangatlah pesat perkembangannya, terutama kota Yogyakarta. Selain kota pelajar dan budaya, Jogja juga menjadi kota yang terkenal banyak objek wisata yang menjadi pusat perhatian baik dalam maupun luar negri. Demi menunjang fasilitas untuk para wisatawan, tentunya banyak yang memanfaatkan kesempatan ini untuk dijadikan penghasilan. Sudah banyak bangunan di Yogyakarta yang menawarkan fasilitas dengan promosi harga yang murah dan berkualitas, salah satunya adalah hotel berbintang.

Dari semua fasilitas hotel yang disediakan pasti memerlukan peralatan, perlengkapan, bahan-bahan untuk operasional mulai dari yang material maupun bahan yang siap pakai. Semua itu berjalan dengan adanya Purchasing Department. Purchasing berhubungan dengan semua department yang ada di hotel, karena semua yang hotel butuhkan menjadi tanggung jawab purchasing. Purchasing bertugas membeli barang permintaan user atau department terkait untuk membeli barang yang dibutuhkan untuk operasional. Purchasing sebelum membeli barang untuk hotel, harus terlebih dahulu mempertimbangkan dengan cost control terhadap item, harga, dan kualitas produk. Jika cost control telah menyetujui pertimbangan tersebut, purchasing baru bisa memesan barang tersebut kepada supplier/toko.

Faktor yang memperlambat storage department dalam proses penerimaan barang biasanya dalam pembuatan Purchase order (PO) terjadi kesalahan, baik kesalahan lupa memasukan PPN maupun keslahan memasukan harga, keterlambatan approve dari manager, dan ada juga supplier mengantarkan barang tidak sesuai dengan Purchase Order dari Purchasing. Ada kendala lain purchasing ketika memesan barang kepada supplier yang sering terjadi di Hotel Jambuluwuk yakni mengenai penunggakan pembayaran kepada supplier dan jika terjadi fluktuatif harga yang tidak stabil. Selanjutnya adalah tugas receiving atau Storage Department yang terbagi menjadi storekeeper dan receiving. Receiver yang akan menerima barang yang telah dipesan oleh purchasing. Sebelum barang diterima, Receiver harus memastikan antara barang yang dipesan, harga, quantity, dan fisik sama dengan purchase order yang telah dibuat oleh purchasing. Setelah barang diterima lalu dicap dan receiver membuat receiving report atas barang tersebut.

\subsection{Tinjauan Pustaka}

\subsubsection{Pengertian Hotel}

Menurut Komar (2014:2) Hotel merupakan organisasi yang kompleks dengan beberapa bagian yang mungkin tidak akan terlihat oleh masyarakat biasa pada umumnya. Sedangkan menurut Sulastiyono (2011:5) Hotel adalah Perusahaan yang dikelola oleh pemiliknya dengan menyediakan pelayanan makanan, minuman dan fasilitas kamar untuk istirahat kepada orang-orang yang sedang melakukan perjalanan dan mampu membayar dengan jumlah yang wajar sesuai dengan pelayanan yang ditentukan tanpa ada perjanjian khusus.

Menurut Rumekso (2009:1) sesuai dengan SK Menparpostel Nomor KM 34. NK 103/MPPT 87 definisi hotel adalah suatu jenis akomodasi yang menggunakan sebagian atau seluruh bangunan untuk menyediakan jasa pelayanan/penginapan, makan, minum serta jasa lainnya bagi umum yang dikelola secara komersial.

Dari beberapa pengertian diatas, dapat disimpulkan bahwa hotel adalah usaha yang menyediakan jasa penginapan, makanan dan minuman serta penunjang lainya dengan memperhitungkan untung atau ruginya, serta bertujuan untuk mendapatkan keuntungan berupa uang sebagai tolak ukurnya.

\subsubsection{Pengertian Sistem}

Menurut Sumarsan (2013:2) Sistem adalah kumpulan kesatuan dan perangkat hubungan satu sama lain. Pendapat lain juga dikemukakan oleh Helmawati dalam Saefullah (2015:14) Sistem berasal dari bahasa Yunani yaitu System yang berarti: (1) keseluruhan yang tersusun dari sekian banyak bagian; (2) hubungan yang berlangsung di antara satuansatuan atau komponen secara teratur. Dengan demikian, kata system berarti himpunan bagian atau komponen yang saling berhubungan secara teratur yang merupakan satu keseluruhan, sehinga pada suatu sistem terdapat beberapa sistem kecil (secondary system, subsystem). 
Secara terminologi, Helmawati dalam Saefullah (2015:14) menguraikan pengertian sistem dapat diartikan sebagai sesuatu yang lebih tinggi daripada hanya merupakan cara, tata, rencana, skema, prosedur, atau metode. Sistem adalah suatu cara yang mekanismenya sering bersifat otomatis.

\subsubsection{Purchasing Department}

Pada perusahaan yang bergerak dalam bidang jasa seperti usaha hotel dan restoran, bagian pembelian sangat penting dan diperlukan keberadaannya. Sangat penting karena peran bagian ini cukup dominan dalam pelaksanaan proses dan prosedur pembelian, baik pembelian barang untuk persediaan/stok digudang maupun pembelian barang yang dipakai langsung untuk keperluan operasional hotel itu sendiri. Pada industri perhotelan atau pada perusahaan umum lainnya, bagian ini dikenal dengan istilah Purchasing Department.

\subsubsection{Pengertian Purchasing}

Menurut Kho (2016) Kata Purchasing berasal dari bahasa Inggris dan sering digunakan dalam industri-industri luar maupun dalam negeri. Jika diterjemahkan langsung, maka purchasing dapat diartikan sebagai Pembelian dalam bahasa Indonesia. Jadi pada dasarnya, purchasing adalah suatu proses pencarian sumber dan pemesanan barang atau jasa untuk kegiatan produksi. Department yang menangani proses purchasing tersebut biasanya disebut dengan Purchasing Department.

Sedangkan menurut Suarsana (2007b:2) Purchasing berasal dari beberapa suku kata dalam bahasa Inggris yaitu: "purchase" tepatnya "to purchase" yang diartikan "membeli" atau melakukan pembelian.

Dilihat dari asal katanya, sebutan atau istilah "purchasing department" dapat diartikan sebagai "salah satu departemen atau sub bagian dari Departemen Akunting, yang mendapat otoritas dari manajemen atau pemilik hotel, untuk melakukan pembelian semua jenis barang keperluan operasional perusahaan atau hotel".

\subsubsection{Storage Department}

Untuk menjaga kontinyuitas operasional, pada sebuah perusahaan atau hotel, sudah barang tentu memerlukan sarana dan fasilitas. Salah satu fasilitas penting yang harus disediakan oleh perusahaan yang bergerak dibidang perhotelan adalah sebuah gudang atau lebih dikenal dalam bahasa asing dengan sebutan "Store-Room".

Menurut Riadi dalam Gunawan (2014:7) "Logistik merupakan seni dan ilmu yang mengatur dan mengontrol arus barang, energi, informasi dan sumber daya lainnya, seperti produk, jasa dan manusia dari sumber produksi ke pasar dengan tujuan mengoptimalkan penggunaan modal".

Sedangkan Nyoman Suarsana (2007b:76) mengatakan bahwa "Gudang atau ruangan gudang adalah sebagai tempat menyimpan barang-barang persediaan keperluan operasional perusahaan atau hotel". Barang persediaan ini disimpan dan dirawat sedemikian rupa sehingga dapat dipertanggung jawabkan keutuhannya oleh staf bagian gudang yang menjaganya.

\subsection{Metode Penelitian}

Penelitian dilakukan dengan menggunakan metode deskriptif, yaitu penelitian yang berusaha untuk mendeskriptifkan atau mengambarkan fenomena yang diteliti secara sistematis factual dan akurat (kusmayadi, 2000). Metode pengumpulan data dengan menggunakan : 1) Studi pustaka/ literature yang terkait dengan objek penelitian. 2) Observasi yaitu dengan mengamati dan meneliti kejadian secara langsung. 3) Wawancara, yaitu dengan bertanya langsung kepada nara sumber.

\subsection{Hasil Penelitian Dan Pembahasan}

PT.ARCS HOUSE memperkenalkan pengembangan Hotel Jambuluwuk Malioboro Yogyakarta pada tahun 2011 Desember Jambuluwuk Malioboro Hotel soft opening. Untuk Jambuluwuk villanya sendiri fasilitas yang diberikan adalah penyewaan villa, ruang pertemuan (banquet), untuk meeting, sporthall, restaurant, outbond, swimming pool, club house, hot and cold water, cable tv with tv chanel, living room, dinning room, kitchen set, privat yard.

1. Sistem kerja Storage dan Purchasing Department di Hotel Jambuluwuk Malioboro Yogyakarta

Hotel Jambuluwuk Malioboro Yogyakarta memiliki satu departemen yang lain dari hotel lainnya, yaitu departemen Material Manajemen yang mana Material Manajemen didalamnya gabungan dari Storage dan Purchasing Section. Ruang kerja yang digabung menjadi satu antara Storage dan Purchasing memudahkan proses kerja apabila menemui suatu hambatan. Dalam proses kerjanya ada beberapa alur yang menjadi tanggung jawab Storage dan Purchasing. Berikut alur kerja mulai dari pengadaan barang dari cabang, permintaan barang untuk user (departemen yang meminta), pembelian barang, sampai penerimaan barang

a. Permintaan/pengadaan barang dari cabang (persetujuan pusat) 


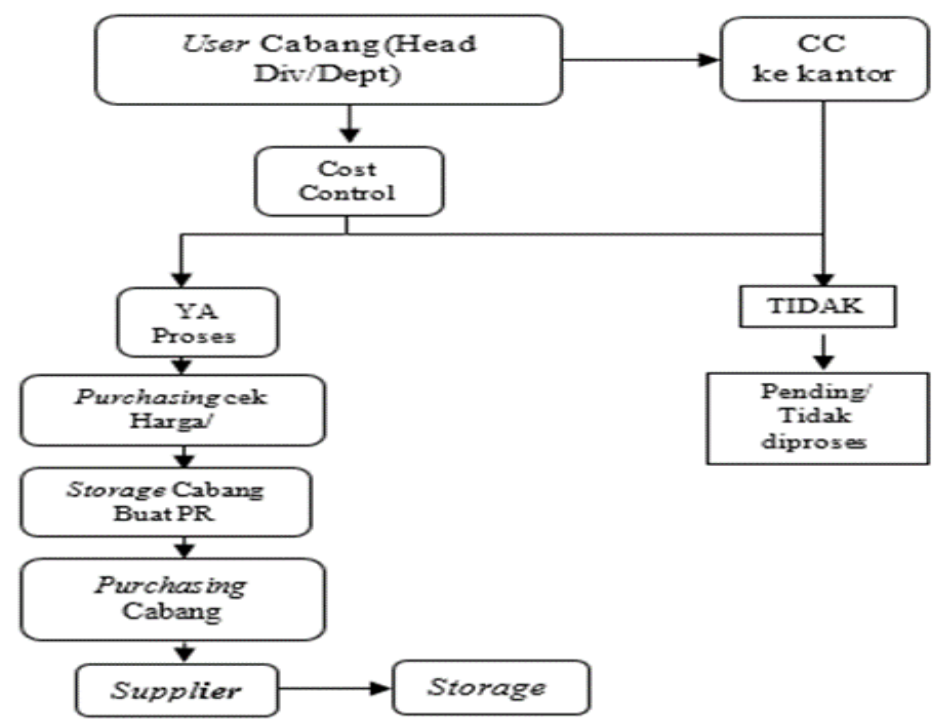

Gambar 1. Proses permintaan/pengadaan barang dari cabang

$\begin{array}{ll}\text { Keterangan proses permintaaan/ } & \text { mengecek harga barang ke toko } \\ \text { pengadaan barang dari cabang } & \text { atau supplier (meminta penawaran } \\ \text { (persetujuan pusat) tersebut adalah: } & \text { harga) dengan limit waktu. }\end{array}$

1. User (departemen yang meminta) cabang membuat pengajuan pengadaan kepada Financial Accounting cabang (Cost Control) dengan memberikan penjelasan mengapa perlu ada pengadaan tersebut berikut perkiraan biaya yang dikeluarkan dan kapan barang tersebut harus ada.

2. Apabila pusat tidak menyetujui, pengadaan barang tersebut pending/tidak diproses. Namun apabila kantor pusat menyetujui, akan dilanjutkan oleh Cost Control.

3. Selanjutnya Cost Control akan meminta Purchasing cabang untuk

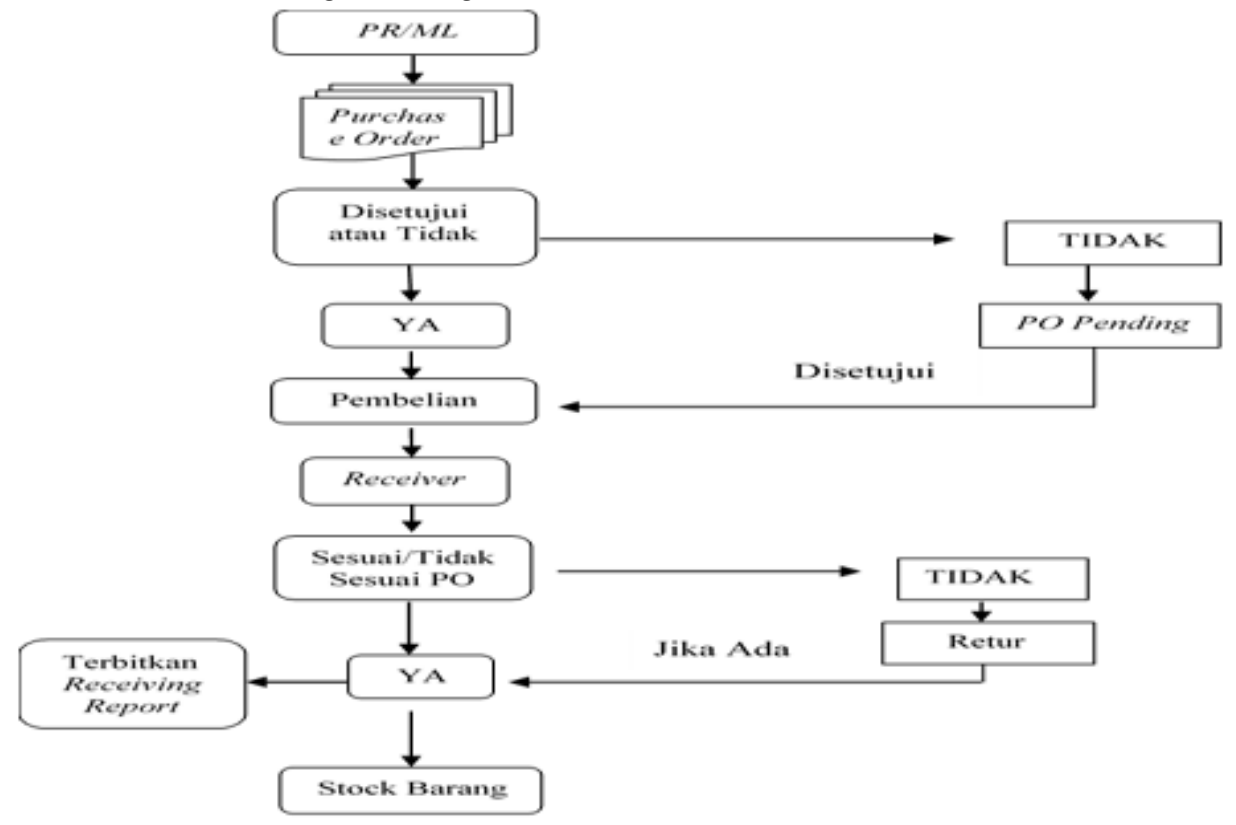

Gambar : 2 Proses Pembelian Barang (Purchasing)
4. Proses dicabang terus berlanjut, bila harga sudah ada dan telah disetujui oleh pusat, maka diterbitkan Purchase Request (PR) oleh storage dan Purchase Order (PO) oleh purchasing di cabang.

5. Jika proses pembeliannya adalah dicabang, maka purchasing cabang yang langsung mengorderkan ke supplier. Jika proses pembelian adalah dipusat maka purchasing cabang mengirimkan Purchae Order (PO) untuk purchasing pusat agar bisa diorder

b. Pembelian Barang (Purchasing) 
Proses Purchasing yakni :

1. Proses pembelian barang setelah dokumen Purchase Request (PR)/Market List (ML) menjadi Purchase Order (PO) oleh Purchasing dan telah disetujui oleh pihak yang bersangkutan, pembelian barang sudah bisa diorder kepada supplier

2. Purchasing membeli barang dengan sistem kontrak dan kontan. Sistem kontrak antara hotel dengan supplier diakukan dengan surat perjanjian. Setelah perjanjian disetujui dan supplier yang bersangkutan dinyatakan menjadi supplier tetap, purchasing menyimpan data supplier untuk dijadikan acuan.

3. Adapun sistem kontan dilakukan khusus untuk pembelian barangbarang dapur yang stoknya sudah habis dan akan segera dipakai/mendadak. Pihak hotel tentunya menyediakan uang dengan jumlah tidak terlalu banyak, istilah lainnya kas kecil (petty cash). Pembelian menggunakan kas kecil biasanya dilakukan di toko/supermarket yang dekat dengan lokasi hotel. Meminta uang kas kecil untuk keperluan mendadak tersebut harus melalui dokumen Bon Sementara. Dokumen ini berlaku hanya untuk pembelian cash saja.

4. Purchase Order (PO) pending apabila tidak disetujui oleh Cost Control.

5. Pembelian dilakukan oleh Purchasing, receiver menerima dan mengecek barang dengan nota. Apabila barang sesuai dengan Purchase Order, maka receiver membuat receiving report atas barang tersebut.

6. Selanjutnya Store keeper menata barang datang dan mencatat ke dalam Bin Card untuk distok.

c. Penerimaan Barang (Receiving)

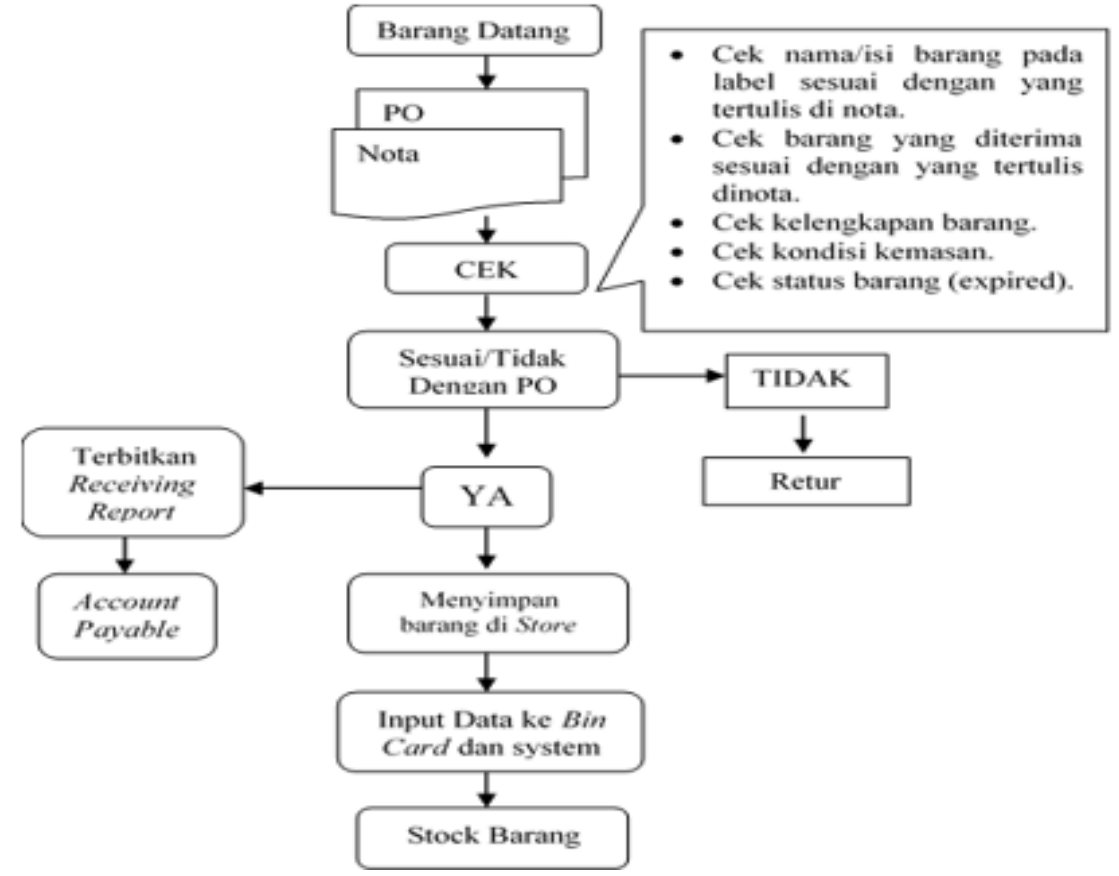

Gambar : 3 Proses Penerimaan Barang (Receiving)

Penjelasan mengenai receiving yakni :

1. Penerimaan barang dilakukan oleh receiver setelah barang pesanan dari Purchasing diterima, receiver mengecek barang tersebut berdasarkan kuantitas, kualitas, harga, dan delivery barang tersebut dengan menyesuaikan Purchase Order (PO) dan nota.

2. Apabila ada perbedaan antara barang yang dikirim dengan Purchase Order (PO), maka receiver berhak mengembalikan barang tersebut kepada supplier. Sedangkan apabila barang yang datang sesuai Purchase Order (PO), maka barang tersebut diterima dan ditandatangani oleh receiver serta ditulis tanggal diterima barang tersebut dan dicap "RECEIVING".

3. Selanjutnya receiver menerbitkan receiving report rangkap 3 (tiga) yang telah ditandatangani dan disatukan dengan faktur, Purchase Order, dan Purchase Request atau Market List. 
4. Setelah receiving report tersebut lengkap ditandatangani oleh user, storage dan cost control, kemudian receiving report tersebut dibagi berdasarkan masing-masing rangkap. Receiving report yang sudah dibagi tersebut yang asli diserahkan ke bagian Account Payable (AP) untuk bukti pengakuan hutang usaha.

5. Store keeper menata barang datang menggunakan sistem LIFO (Last In First Out). Barang datang tersebut diinput kedalam system dan Bin Card sesuai nama dan jumlah barang. Barang yang distok bukan barang yang urgent, namun barang yang pengambilannya sewaktu-waktu ketika dibutuhkan pada saat itu.

2. Faktor yang Memperlambat Storage Department dalam Proses Penerimaan Barang

Penerimaan barang dari supplier yang datang kehotel biasanya tidak semudah yang dilihat. Dari sekian banyak barang yang datang, biasanya terdapat kesalahan dari supplier dan kesalahan dari Purchasing. Berikut ini beberapa faktor yang memperlambat pekerjaan Storage khususnya Receiver dalam proses penerimaan barang, yaitu:

a. Kesalahan dari Purchasing dalam membuat Purchase Order (PO).

Purchasing dalam memasukan harga barang terdapat selisih dengan nota dari supplier. Kesalahan seperti itu terjadi karena Purchasing lupa tidak memasukan PPn atau salah memasukan harga. Ketika Receiver mengecek Purchase Order (PO) dan nota dari supplier ternyata ada kesalahan dan perbedaan, Receiver boleh tidak menerima barang tersebut karena Purchase Order (PO) masih harus diganti dengan harga yang sesuai dengan surat penawaran dari supplier. Hal ini akan memperlambat Receiver dalam memproses receiving report. Purchase Order (PO) yang seharusnya sudah bisa direceiving tetapi karena kesalahan tersebut, Purchase Order $(P O)$ harus pending terlebih dahulu.

b. Keterlambatan approve dari General Manager .

Supplier sudah mengantarkan barang namun Purchase Order (PO) belum siap karena belum mendapat approve dari General Manager, biasanya untuk Purchase Order (PO) barang-barang Market List (ML) seperti buah dan sayur. Maka dari Purchasing membuat
Purchase Order (PO) bayangan agar barang tersebut dapat diterima. Apabila Purchase Order (PO) masih bayangan, maka Receiver belum bisa membuat receiving report atas barang tersebut. Receiver harus menunggu Purchase Order (PO) asli dari Purchasing setelah Purchase Order (PO) tersebut telah disetujui.

c. Supplier mengantarkan barang tidak sesuai dengan $P O$ dari Purchasing.

Biasanya supplier mengantarkan barang bisa kurang atau lebih dari jumlah yang diminta. Ketika supplier mengantarkan barang tetapi kurang dari jumlah di Purchase Order (PO), maka Purchase Order (PO) tersebut dipartial oleh Receiver. Maksudnya adalah barang yang didatangkan oleh supplier tetap diterima namun supplier harus mengantarkan kembali kekurangan barang pada esok harinya. Purchase Order (PO) asli dari barang tersebut tetap dibuat receiving report berdasarkan jumlah barang yang diterima. Namun sebelumnya Purchase Order (PO) asli dan Purchase Request $(P R)$ di fotocopy masing-masing 2 lembar untuk kelengkapan kekurangan barang yang akan diantar oleh supplier pada hari berikutnya. Dari semua kekeliruan baik dari Purchasing maupun dari supplier, pihak storage bekerja sesuai dengan ketentuan dan SOP yang berlaku di Hotel Jambuluwuk Malioboro Yogyakarta.

3. Kendala Purchasing dalam Pemesanan Barang kepada Supplier

Memesan barang kepada supplier adalah tanggung jawab yang pasti untuk Purchasing Section. Purchasing harus bisa memenuhi permintaan dari user untuk barang-barang yang dibutuhkan dari semua department di hotel. Karena banyaknya kebutuhan hotel yang harus terpenuhi, purchasing harus pintar memilih supplier dan membandingkan supplier mana yang cocok untuk dijadikan acuan dalam pemesanan barang. Purchasing dalam memesan barang kepada supplier terkadang tidak mudah dan butuh mental yang kuat. Kendala Purchasing ketika memesan barang kepada supplier yang sering terjadi di Hotel Jambuluwuk Malioboro Yogyakarta yaitu:
a. Penunggakan pembayaran kepada supplier .
Purchasing ketika order barang kepada supplier terutama melalui telephone, salah satu supplier biasanya ada yang tidak bersedia mengantarkan barangnya 
dikarenakan penunggakan pembayaran yang sudah jatuh tempo. Dalam keadaan yang seperti ini, purchasing yang tidak ada hubungannya dengan pembayaran harus menanggung pertanyaan dari pihak supplier kapan pembayaran akan dilakukan. Purchasing hanya mampu memberikan jawaban bahwa dari pihak Purchasing akan membantu membicarakan hal pembayaran dengan Account Payable. Alasan supplier ketika tidak bersedia mengantarkan barang karena tunggakan pembayaran, biasanya supplier mengatakan kepada Purchasing bahwa barang yang dipesan kosong/belum tersedia. Ketika hal ini terjadi, Purchasing harus pintar mencari supplier pengganti yang bersedia mengantarkan barang ke hotel. Jika barang yang dibutuhkan jumlahnya sedikit dan bisa dibeli di toko/supermarket terdekat, purchasing memilih untuk membeli barang tersebut secara cash. Untuk proses pembayaran supplier, dari pihak purchasing meminta kepada Accounting terutama Account Payable yaitu bagian hutang usaha untuk segera di Follow Up demi kelancaran pemesanan barang dan hubungan yang baik dengan supplier tetap terjaga.

b. Harga yang fluktuatif.

Perubahan harga yang fluktuatif memang menjadi kendala tersendiri bagi Purchasing Department di Hotel Jambuluwuk Malioboro Yogyakarta. Ketika Purchasing sudah memesan barang namun secara tiba-tiba terjadi perubahan harga naik maupun turun oleh pihak supplier, Purchasing harus revisi Purchase Order (PO) dengan harga yang baru namun harus dengan persetujuan dari Accounting Department terlebih dahulu.

\subsection{Kesimpulan}

Berdasarkan hasil penelitian yang dilakukan di Hotel Jambuluwuk Malioboro Yogyakarta mengenai sistematika antara Storage dan Purchasing Department dalam mengupayakan tanggung jawab, maka dapat diambil kesimpulan dan saran untuk meningkatkan kualitas pelayanan di hotel.

1. Storage dan Purchasing Department dalam memenuhi tanggung jawab di Hotel Jambuluwuk Malioboro Yogyakarta mulai dari permintaan pengadaan barang dari cabang dan harus disetujui pusat terlebih dahulu, permintaan dari user kepada Store Keeper untuk barang yang dibutuhkan, pembelian yang dilakukan oleh Purchasing untuk barang yang sudah menipis stoknya dan permintaan dari user menggunakan dokumen Purchase Request (PR) dan diproses menjadi Purchase Order (PO), dan penerimaan barang oleh Receiver dengan mengecek barang, jumlah, dan kualitas barang dengan Purchase Order (PO) dan nota dari supplier. Dengan adanya kerjasama tim yang baik dalam proses tersebut akan menciptakan hasil kerja yang memuaskan dan saling mendukung.

2. Adanya kesalahan maupun kekeliruan dari Purchasing dan dari pihak Supplier yang membuat lambatnya pekerjaan Receiver dalam menerima barang, menunjukan masih ada kekurangan dalam kinerja karyawan hotel maupun dari supplier.

3. Usaha Purchasing ketika supplier tidak bersedia mengantarkan barang karena penunggakan pembayaran dan perubahan harga yang secara tiba-tiba, Purchasing bekerja sesuai ketentuan yang berlaku di hotel. Masalah pembayaran kepada supplier, Account Payable berusaha untuk menutup kekurangan tersebut dengan membicarakan bersama General Manager dan pusat demi kelancaran pemesanan barang dan hubungan yang baik antara hotel dengan supplier.

4. Kerjasama yang baik antara Storage dan Purchasing Department menciptakan hasil kerja yang memuaskan bagi tamu maupun bagi hotel demi kelancaran operasional.

\section{Daftar Pustaka}

[1] Helmawati. 2015. Sistem Informasi Manajemen Pendidikan Agama Islam. Bandung: PT Remaja Rosdakarya.

[2] Kho, Budi. 2016. Pengertian Purchasing \& Prosedur Dalam Proses Purchasing. Diambil dari: http://www.ilmumanajemenindustri.com/pen gertian-purchasing-prosedur- dalamproses-purchasing/ (28 April 2017).

[3] Komar, Richard. 2014. Hotel Management (Manajemen Perhotelan). Jakarta: PT Grasindo

[4] Kusmayadi dan Sugiarto, E, 2000. Metodologi Penelitian Dalam Bidang Pariwisata, Jakarta, PT.Gramedia.

[5] Riadi, Muchlisin. 2016. Pengertian Dan Ativitas Logistik. Diambil dari http://www.kajianpustaka.com/2016/04/peng ertian-dan-aktivitas-logistik.html (28 April 2017).

[6] Rumekso. 2009. Housekeeping Hotel Floor Section. Yogyakarta: ANDI. 
[7] Suarsana, Nyoman. 2007. Pengendalian Biaya Departemen F\&B di Perhotelan. Yogyakarta: Graha IImu.

[8] Suarsana, Nyoman. 2007. Siklus Pengadaan Barang Aplikasi di Perhotelan dan Restoran. Yogyakarta: Graha IImu.
[9] Sulastiyono, Agoes. 2011. Management Penyelenggaraan Hotel. BandungAlfabeta.

[10] Sumarsan, Thomas. 2013. Sistem Pengendalian Manajemen. Jakarta: PT Indeks. 